\title{
The role of e-marketing and e-CRM on e-loyalty of Indonesian companies during Covid pandemic and digital era
}

\author{
Haudia $^{a}$, Erna Retno Rahadjeng ${ }^{\mathrm{b}}$, Ruby Santamoko ${ }^{a}$, Riyan Sisiawan Putra ${ }^{\mathrm{c}}$, Dwi Purwoko ${ }^{\mathrm{d}}$, Dewi \\ Nurjannah $^{\mathrm{e}^{*}}$, Intan Rachmina Koho ${ }^{\mathrm{f}}$, Hadion Wijoyo ${ }^{\mathrm{g}}$, Ade Onny Siagian ${ }^{\mathrm{h}}$, Yoyok Cahyono ${ }^{\mathrm{f}}$ and Agus \\ Purwanto ${ }^{i}$
}

${ }^{a}$ STAB Dharma Widya, Indonesia

${ }^{b}$ Faculty of Economics and Business University of Muhammadivah Malang, Indonesia

${ }^{c}$ Universitas Nahdlatul Ulama Surabaya, Indonesia

${ }^{d}$ Lembaga Ilmu Pengetahuan Indonesia (LIPI), Indonesia

${ }^{e}$ Faculty of Economics and Business University of Muhammadiyah Malang, Indonesia

${ }^{f}$ Universitas Pramita Indonesia, Indonesia

${ }^{g}$ STMIK Dharmapala Riau, Indonesia

${ }^{h}$ Universitas Bina Sarana informatika, Indonesia

${ }^{i}$ AgusPati Research Instituta, Indonesia

\section{H R O N I C L E}

\section{Article history:}

Received September 18, 2020

Received in revised format May

8, 2021

Accepted September 62021

Available online

September 62021

Keywords:

E-Marketing

E-CRM

E-Loyalty

E-Commerce

\author{
A B S T R A C T
}

The aim of this research is to analyze the effects of e-Marketing, e-CRM and e-Marketing on eLoyalty and company performance. The study is quantitative with a questionnaire approach. Data processing tools use the SmartPLS 3.3.3 software. The primary data collection method was by distributing online questionnaires through online surveys to 286 managers of non-e-commerce companies during covid pandemic and digital era. The regression test results show the e-Marketing has a significant effect on Company Performance, e-CRM has significant effect on Company Performance, e-Marketing has no significant effect on e-Loyalty, e-CRM has no significant effect on e-Loyalty), e-Loyalty has no significant effect on Company Performance, e-CRM has no significant effect on business sustainability through e-Loyalty. Finally, e-Marketing has no significant effect on Company Performance through e-Loyalty. That means e-marketing and eCRM have a relationship and influence on e-loyalty both individually and simultaneously.

(C) 2022 Growing Science Ltd. All rights reserved.

\section{Introduction}

In the digital era, marketing trends continue to develop along with the development of increasingly sophisticated technology with the presence of the internet world. Digital marketing is present as an innovation in the world of marketing. Digital marketing is the process of marketing a product or service via digital or the internet. The advantages of customer relationship management (CRM) according to Prameswari et al. (2020) and Praditya (2020) are to make customers happy by providing choices for the products and services provided, problem solving and fast response, easy and fast access to information. The main goal of CRM is not to retain customers who will turn into competitors but to simply serve customers, its main purpose is to identify, maintain, and retain the right customers to trigger repeated use over products or services produced by the company (Asbari, 2021). E-CRM uses the internet by creating a website that can be accessed by customers from various times and places to increase customer satisfaction, customer loyalty and competitive advantage of the company where the knowledge of the customer will be built individually which indirectly stimulates the marketing strategy of the company. According to Pramono et al. (2021), Prameswari et al. (2020) and Praditya (2020), CRM is the process of building and maintaining profitable customer relationships to provide value and customer satisfaction. CRM is used to manage detailed information about the customer individually and carefully manages the relationship with the customer for the purpose of * Corresponding author

E-mail address: dewi n@umm.ac.id (D. Nurjannah)

(C) 2022 Growing Science Ltd. All rights reserved. doi: $10.5267 /$ j.uscm.2021.9.006 
maximizing customer satisfaction. E-CRM refers to customer relationship management electronic or more simply is a webbased CRM.

Social media is an effective medium to use when we are doing a digital marketing campaign. By using social media, we can connect with our customers or audiences who have the potential to become our customers. Currently, social media is still the main thing that people from all walks of life are interested in. According to Aggarwal et al. (2021), Alzaam et al. (2021) and Asbari et al. (2021), e-Marketing is the use of information technology in the process of making, communicate, and convey value (value) to customers, and can also be used to maintain customer relationships for mutual benefit (Strauss \& Ansary in Salehi et al., 2012). Companies need to consider electronic marketing opportunities; therefore, they need to know how to create an attractive website. Research on the relationship between sports website quality, e-satisfaction, and e-loyalty (Hur et al., 2011) resulted in the conclusion that loyalty to the sports team website which is a website non-e-commerce is more likely to occur due to positive perceptions of being a sports fan satisfaction on the website that is obtained from the quality of the website itself. Hence the website to be a means of e-marketing must have good quality and satisfy users to generate loyalty. There are 13 criteria that can be used to evaluate a website (Selim, 2011). Three of which are used in this research is accessibility (level of access ability of a website), currency / timeliness related to various updates available on the website, and accuracy / credibility which is how factual and verifiable information and material provided by the website. According Nugroho et al. (2020), Nguyen et al. (2021), Pramono et al. (2021), Prameswari et al. (2020) and Praditya (2020), the company website does not serve online transactions. If e-marketing is the process of delivering value to customers, e-CRM is a system which is used to maintain the conveyed value. E-CRM is an electronic customer relationship management. E$\mathrm{CRM}$ is the use of digital communication technology to maximize business relationships with existing customers and continue to encourage the use of online services.

The existence of e-CRM on the company's website should be able to generate usage on a sustainable website. According to Alzaam et al. (2021), Amri et al. (2021) and Asbari et al. (2021), the implementation of e-CRM can be expected to produce value significant for companies and customers in an age when society is connected to one another (Jih \& Lee, 2011). Therefore, with the increasing number of internet users, e-CRM is the right solution for companies in maintaining customer relationships. In this research, e-CRM is measured by 3 dimensions, namely, information quality, customer service efficiency, and ease of navigation (Hamid et al., 2011). E-loyalty is an extension of the conventional loyalty concept that is applied online. E-loyalty is the intention to visit the website again with or without online transactions (Hur et al., 2011). For this reason, because the company website is non-e-commerce, which means it does not serve transactions, in in this study, eloyalty was measured using 3 out of 4 indicators without including action, namely, cognitive, affective, and conative with each indicator is preference, positive attitudes, and revisit (Hur et al., 2011). The purpose of this research is to analyze the relationship of the e-Marketing (EM) and e-CRM (EC) on Company Performance, e-Marketing (EM) and e-CRM (EC) on e-Loyalty.

Hypotheses Development

According to Nugroho et al. (2020), Nguyen et al. (2021), Pramono et al. (2021), e-Marketing (EM) has a significant effect on Company Performance (CP), According to Prameswari et al. (2020) and Praditya (2020), e-Marketing (EM) has a significant effect on Company Performance (CP).

$\mathbf{H}_{1}$ : e-Marketing (EM) has a positive effect on Company Performance (CP).

According to Priadana et al. (2021) and Purwanto et al. (2021), e-CRM (EC) has a significant effect on Company Performance (CP). According to Pham et al. (2021), Quddus et al. (2020) and Rahaman et al. (2021), e-CRM (EC) has a significant effect on Company Performance (CP).

$\mathbf{H}_{2}$ : e-CRM (EC) has a positive effect on Company Performance (CP).

According to Priadana et al. (2021), Purwanto et al. (2021), Pham et al. (2021), e-CRM (EC) has a significant effect on Company Performance (CP). According to Quddus et al. (2020) and Rahaman et al. (2021), e-CRM (EC) has a significant effect on Company Performance (CP).

H3: e-Marketing (EM) has a positive effect on e-Loyalty (EL).

According to Yunarsih et al. (2020), Wanasida et al. (2021), e-CRM (EC) has a significant effect on e-Loyalty (EL). According to Alzaam et al. (2021), Amri et al. (2021) and Asbari et al. (2021), e-CRM (EC) has a significant effect on eLoyalty (EL).

H4: e-CRM (EC) has a positive effect on e-Loyalty (EL). 
According to Priadana et al. (2021) and Purwanto et al. (2021), e-Loyalty (EL) does not have any significant effect on Company Performance (CP). According to Pham et al. (2021), Quddus et al. (2020) and Rahaman et al. (2021), e-Loyalty (EL) does not have any significant effect on Company Performance (CP).

Hs: e-Loyalty (EL) has a positive effect on Company Performance (CP).

According to Asbari et al. (2021), e-CRM (EC) does not have any significant effect on Company Performance (CP) through e-Loyalty (EL). In addition, Astuti et al. (2020) and Basri et al. (2020) state that e-CRM (EC) has not significant effect on Company Performance (CP) through e-Loyalty (EL).

H6: e-CRM (EC) has a positive effect on Company Performance (CP) through e-Loyalty (EL).

According to Affandi et al. (2020), Budi et al. (2020), e-Marketing (EM) has a significant effect on Company Performance (CP) through e-Loyalty (EL). Bernarto et al. (2020), Fahmi et al. (2020), Hartono and Maksum (2020) state that e-Marketing (EM) has a significant effect on Company Performance (CP) through e-Loyalty (EL).

H7: e-Marketing (EM) has a positive effect on Company Performance (CP) through e-Loyalty.

\section{Research Method}

This research is quantitative research with a questionnaire approach. Data processing tools use the SmartPLS 3.3.3 software. The primary data collection method was by distributing online questionnaires to 286 managers of non-e-commerce companies in Banten Indonesia. In this study, we distributed questionnaires through online surveys to 286 managers of non-e-commerce companies. The questionnaire consisted of two parts. The first part contains questions to collect respondents' demographic information. The second part is the main component of the questionnaire that is statements related to the research variables. Samples were taken from the Indonesian people with the number of respondents was 286 respondents. Fig. 1 presents the structure of the proposed study.

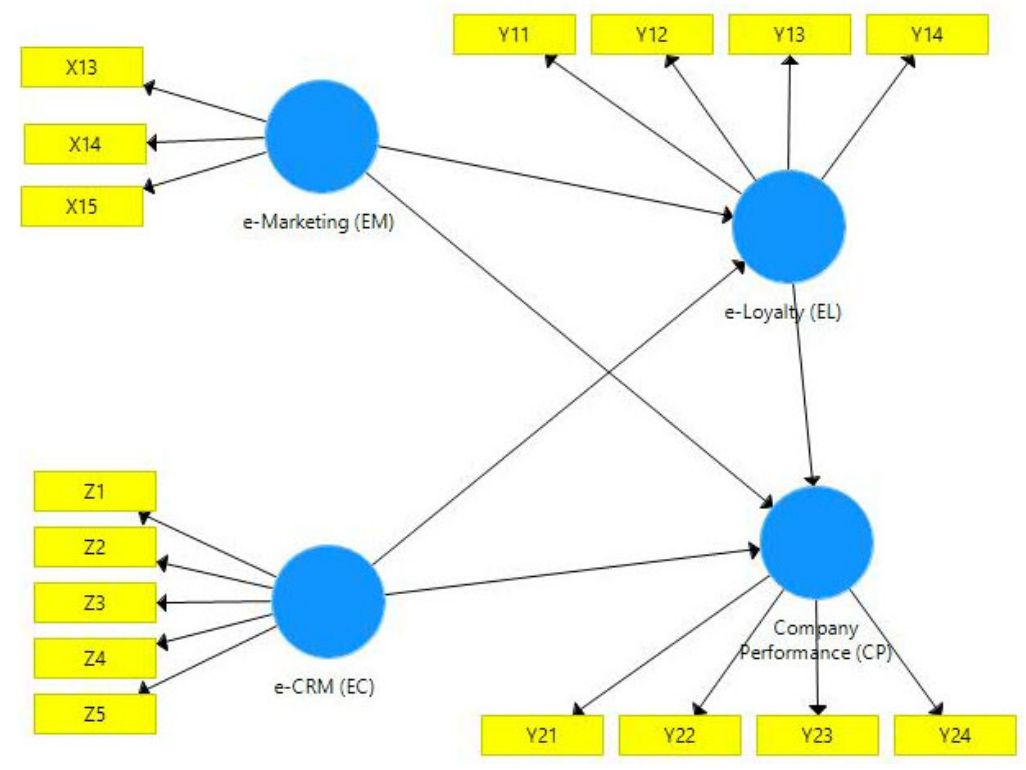

Fig. 1. Research Model

\section{Results and Discussion}

\subsection{Test Results of the Validity and Reliability of Research Indicators}

First testing phase of the measurement model includes testing for convergent validity, discriminant validity and composite reliability. According to Yunarsih et al. (2020), Naushad (2021), Wanasida et al. (2021), Alzaam et al. (2021), Amri et al. (2021) and Asbari et al. (2021), the results of the PLS analysis can be used to test the research hypothesis if all indicators in the PLS model have met the requirements of convergent validity, discriminant validity and reliability testing. Convergent validity test is done by looking at the loading factor value of each indicator against the construct. In most references, a factor weight of 0.5 or more is considered to have sufficiently strong validation to explain latent constructs (Purwanto,2021). In this 
study, the minimum limit for the accepted loading factor is 0.5 , provided that the AVE value of each construct is $>0.5$ (Asbari, 2021).

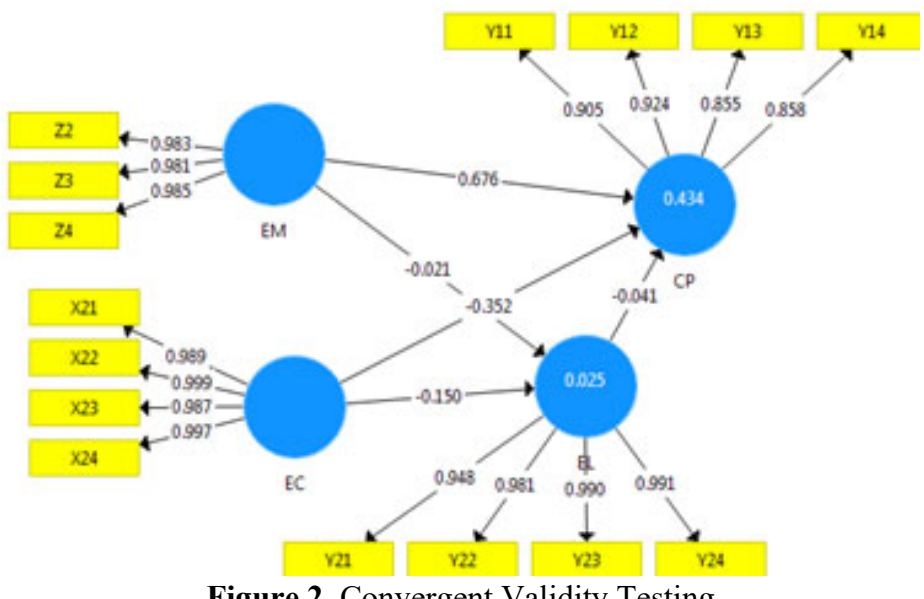

Figure 2. Convergent Validity Testing

Based on the estimation results of the PLS model in Fig. 2, all indicators have a loading factor value above 0.5 so that the model has met the convergent validity requirements. According to Purwanto et al. (2020) the loading factor value of each indicator, convergent validity was also assessed from the AVE value of each construct. The AVE value for each construct of this study is more than 0.5 . So, the convergent validity of this research model has met the requirements. The value of loadings, Cronbach's alpha, composite reliability and AVE for each complete construct can be seen in Table 1:

Table 1

Cronbach's Alpha, Composite Reliability, and Average Variance Extracted (AVE)

\begin{tabular}{cccc}
\hline & Cronbach's Alpha & rho_A & Composite Reliability \\
CP & 0.91 & 0.927 & 0.936 \\
EC & 0.995 & 0.999 & 0.997 \\
EL & 0.985 & 1.003 & 0.785 \\
EM & 0.982 & 0.984 & 0.986 \\
\hline
\end{tabular}

\subsection{Construction Reliability Testing}

Construct reliability can be assessed from the Cronbach's alpha value and the composite reliability of each construct. The recommended composite reliability and Cronbach's alpha value is more than 0.7. (Asbari, 2020). The results of the reliability test in Table 1 above show that all constructs have composite reliability and Cronbach's alpha values are greater than 0.7 ( $>$ 0.7). In conclusion, all constructs have met the required reliability. Discriminant validity is done to ensure that each concept of each latent variable is different from other latent variables. The model has good discriminant validity if the AVE square value of each exogenous construct (the value on the diagonal) exceeds the correlation between this construct and other constructs. The results of the discriminant validity test show that all constructs have a square root value of AVE above the correlation value with other latent constructs (through the Fornell-Larcker criteria) so that it can be concluded that the model has met discriminant validity. The effect test was performed using the t-statistic test in the partial least squared (PLS) analysis model using the SmartPLS 3.0 software. With the bootstrapping technique, the R Square value and the significance test value are obtained as shown in Table 2:

Table 2

R Square

\begin{tabular}{ccc}
\hline & R Square & R Square Adjusted \\
\hline CP & 0.434 & 0.427 \\
EL & 0.025 & 0.017 \\
\hline
\end{tabular}

Based on Table 2 above, the R-Square value for company performance is 0.434 , which means that company performance variable can be explained by e-Marketing (EM), e-CRM (EC), e-Loyalty (EL), the value of R-Square for financial performance (FP) is 0.025 , which means that the e-Loyalty (EL) variable can be explained by e-Marketing (EM) and e-CRM (EC).

\subsection{Hypothesis Testing}

Hypothesis testing in PLS is also known as the inner model test. This test includes a significance test for direct and indirect effects as well as a measurement of the magnitude of the influence of exogenous variables on endogenous variables. Multiple 
linear regression analysis produces a variety of outputs that can be used for testing by various methods. Among them is the coefficient of determination to find out the value of the contribution of both independent variables to the dependent and $t$ test for significance simultaneous influence, as well as the $t$ test for the significance of the effect of individual independent variables. However, before that the correlation test was carried out first to confirm the existence of a relationship from each independent variable on the dependent variable.

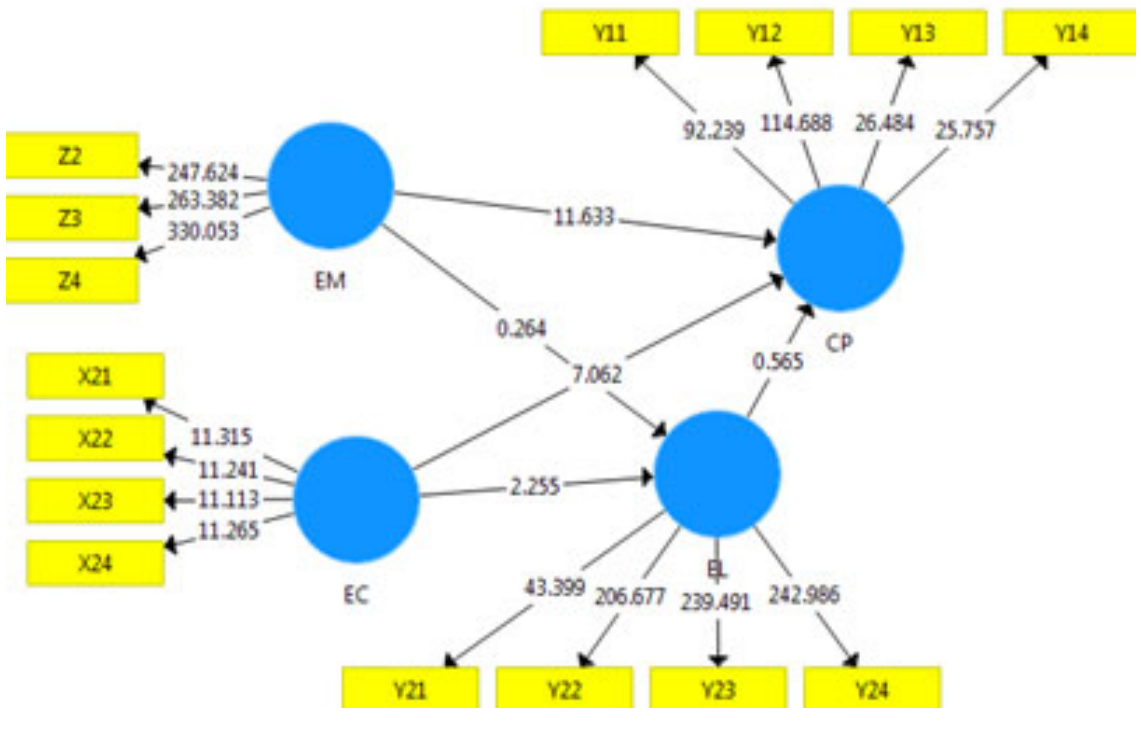

Fig. 3. Hypotheses Testing

The results of hypothesis testing for all variables that have a direct effect are shown in Fig. 3 and Table 3:

Table 3

Hypotheses Testing Direct effect

\begin{tabular}{ccc}
\hline Hypotheses & T Statistics \\
\hline $\mathrm{EM} \rightarrow \mathrm{CP}$ & 11.633 & 0.264 \\
$\mathrm{EM} \rightarrow \mathrm{EL}$ & 7.062 & 0.000 \\
$\mathrm{EC} \rightarrow \mathrm{CP}$ & 2.255 & 0.901 \\
$\mathrm{EC} \rightarrow \mathrm{EL}$ & 0.000 & 0.001 \\
$\mathrm{EL} \rightarrow \mathrm{CP}$ & 0.565 & 0.875 \\
$\mathrm{EC} \rightarrow \mathrm{EL} \rightarrow \mathrm{CP}$ & 0.124 & 0.605 \\
\hline $\mathrm{EL} \rightarrow \mathrm{CP}$ & 0.901 & \\
\hline
\end{tabular}

The first hypothesis: The effect of e-Marketing (EM) on Company Performance (CP)

The regression test result shows the result of the $\mathrm{p}$ value is equal to $0.000<0.050$, which means e-Marketing (EM) has a significant effect on Company Performance (CP). This means that an increase in digital marketing (DM) will encourage Company Performance (CP). The results of this study are in line with Nugroho et al. (2020), Nguyen et al. (2021), Pramono et al. (2021), Prameswari et al. (2020) and Praditya (2020).

The second hypothesis: The effect of e-CRM (EC) on Company Performance (CP)

The regression test result shows the result of the $\mathrm{p}$ value is equal to $0.000<0.050$, which means e-CRM (EC) has a significant effect on Company Performance (CP. This means that an increase in e-CRM (EC) will encourage Company Performance (CP and a decrease in e-CRM (EC) will encourage a decrease in Company Performance (CP). The results of this study are in line with Priadana et al. (2021), Purwanto et al. (2021), Pham et al. (2021), Quddus et al. (2020) and Rahaman et al. (2021).

The third hypothesis: The effect of e-Marketing (EM) on e-Loyalty (EL)

The regression test result shows that the $p$ value is not significant, i.e. $0.981>0.050$, which means e-Marketing (EM) has not significant effect on e-Loyalty (EL). This means that an increase in e-Marketing (EM)) will not encourage e-Loyalty (EL) and a decrease in e-Marketing (EM) will not encourage a decrease in e-Loyalty (EL). The results of this study are in line with findings of Singhdong et al. (2021), Suheny et al. (2020), Syafri et al. (2021), Tan et al. (2021) and Tran and Truong (2021). 
Based on regression test results, we learn that the result of the $p$ value is not significant, i.e., $p$ value is $0.746>0.050$, which means e-CRM (EC) does not have any significant effect on e-Loyalty (EL). This means that an increase in e-CRM (EC) will not encourage e-Loyalty (EL) and a decrease in e-CRM (EC) will not encourage a decrease in e-Loyalty (EL). The results of this study are in line with Yunarsih et al. (2020), Wanasida et al. (2021), Alzaam et al. (2021), Amri et al. (2021) and Asbari et al. (2021).

\section{The fifth hypothesis: The effect of e-Loyalty (EL) on Company Performance (CP)}

Based on regression test results, the result of the $p$ value yields a significant $p$ value of $0.875<0.050$, which means e-Loyalty (EL) has no significant effect on Company Performance (CP). This means that an increase in e-Loyalty (EL) will not encourage Company Performance (CP) and a decrease in e-Loyalty (EL) will not encourage a decrease in Company Performance (CP). The results of this study are consistent with Priadana et al. (2021), Purwanto et al. (2021), Pham et al. (2021), Quddus et al. (2020) and Rahaman et al. (2021).

The sixth hypothesis: e-CRM (EC) has a positive effect on Company Performance (CP) through e-Loyalty (EL)

Based on regression test results, we realize that the result of the $\mathrm{p}$ value is significant since $\mathrm{p}$-value is $0.605>0.050$, which means e-CRM (EC) does not have any significant effect on business sustainability (BS) through e-Loyalty (EL).This means that an increase in e-CRM (EC) will not encourage Company Performance (CP) through e-Loyalty (EL) and a decrease in eCRM (EC) will not encourage a decrease in Company Performance (CP) through e-Loyalty (EL). The results of this study have already been confirmed by Asbari et al. (2021), Astuti et al. (2020) and Basri et al. (2020).

The seventh hypothesis: e-Marketing (EM) has a positive effect on Company Performance (CP) through e-Loyalty (EL)

Based on regression test results, we understand that the $\mathrm{p}$ value is not significant since $\mathrm{p}$ value is $0.859>0.050$, which means e-Marketing (EM) does not have any significant effect on Company Performance (CP) through e-Loyalty (EL). This means that an increase in e-Marketing (EM) will not encourage Company Performance (CP) through e-Loyalty (EL) and a decrease in e-Marketing (EM) may not yield to any decrease in Company Performance (CP) through e-Loyalty (EL). The results of this study are in line with Affandi et al. (2020), Budi et al. (2020), Bernarto et al. (2020), Fahmi et al. (2020), Hartono and Maksum (2020).

\subsection{Discussion}

Correlation testing for each independent variable shows that there is a strong relationship between most independent variables and the dependent variable. E-marketing has a strong and positive relationship with e-loyalty. Likewise, e-CRM has a strong and positive relationship with e-loyalty. e-CRM maintains a stronger effect than e-marketing on e-loyalty. This indicates an e-CRM theory should have a bigger effect on e-loyalty than with e-marketing towards e-loyalty. Several factors must be considered regarding the related variables. Most users feel that the information available on the website is not entirely available during the access period and the website URL (address) is difficult to remember and willingness to visit the website again gets the lowest score among all the factors studied. For this reason, it is better if users are willing to re-access the website and companies need to pay attention to provide useful information for users as well as adding a short tutorial for users who find it difficult to use the website. According to Affandi et al. (2020), Budi et al. (2020), Bernarto et al. (2020), Fahmi et al (2020), Hartono and Maksum (2020), e-loyalty is affected by e-marketing and e-CRM, with e-CRM delivering influence that tends to be greater. Companies can pay attention to e-marketing and e-CRM to further improve e-loyalty because the results of the analysis show a significant positive effect of these two factors. According Singhdong et al. (2021), Suheny et al. (2020), Syafri et al. (2021), Tan et al. (2021) and Tran and Truong (2021) e-loyalty on the Marketing Communication company website is considered good which indicates an effective company website. However, this is likely as well influenced by factors other than e-marketing and e-CRM. This is because $68.4 \%$ of the influence is given by factors not analyzed in this study. The results of this study state that e-loyalty on the company website Marketing Communication has a relationship and is influenced by marketing and e-CRM. The company can increase the number of website visits through e-loyalty which is influenced by e-marketing and e-CRM by paying attention to various indicators.

\section{Conclusion}

The regression test results have shown that e-Marketing has a significant effect on Company Performance, e-CRM has a significant effect on Company Performance, e-Marketing has not maintained any significant effect on e-Loyalty, e-CRM has not had any significant effect on e-Loyalty, e-Loyalty has not had any significant effect on Company Performance, e-CRM has not provided any significant effect on business sustainability through e-Loyalty. e-Marketing has had no significant effect on Company Performance through e-Loyalty. That means e-marketing and e-CRM have had a relationship and influence on e-loyalty both individually and simultaneously. E-marketing and e-CRM make an impact with e-CRM as the dominant 
influencing variable. With a CRM application, it is possible for companies to use all the information that has been successfully collected from various sources with customers such as through call centers, the web, field services, and marketing staff. This consistent receipt of information enables better service and sales thanks to a wide variety of important information about these customers. Use of CRM applications realizes step by step business operations. All are intended to achieve specific company targets. The achievement steps are reaching new customers, adding customer value, and maintaining customer loyalty.

\section{References}

Aggarwal, K., Malik, S., Misshra, D. K., \& Paul, D. (2021). Moving from Cash to Cashless Economy: Toward Digital India. The Journal of Asian Finance. Economics and Business, 8(4), 43-54. https://doi.org/10.13106/JAFEB.2021.VOL8.NO4.0043

Alzaam, A. F., \& Almizeed, K. (2021). The Effect of Digital Marketing on Purchasing Decisions: A Case Study in Jordan. The Journal of Asian Finance. Economics and Business, 8(5), 455-463. https://doi.org/10.13106/JAFEB.2021.VOL8.NO5.0455

Amri, W. A. A., Asbari, M., Gazali, G., Novitasari, D., \& Purwanto, A. (2021). The Effect of Religiosity and Service Quality on Job Satisfaction: A Case Study of MSME Employees. International Journal of Social and Management Studies, 2(1), 53-63. https://doi.org/10.5555/ijosmas.v2i1.7

Asbari, M., Dylmoon Hidayat, D., \& Purwanto, A. (2021). Managing Employee Performance: From Leadership to Readiness for Change. International Journal of Social and Management Studies, 2(1), 74-85. https://doi.org/10.5555/ijosmas.v2i1.12

Affandi, A., Sarwani, Sobarna, A., Erlangga, H., Siagian, A. O., Purwanto, A., Effendy, A. A., Sunarsi, D., Wicaksono, W., Suyatin, Ariyanti, E., Wahyitno, Manik, C. D., Juhaeri, \& Gunartin, (2020) Optimization of MSMEs Empowerment in Facing Competition in the Global Market during the COVID-19 Pandemic Time. Systematic Reviews in Pharmacy, 11 (11), 1506-1515. doi:10.31838/srp.2020.11.213

Budi, \& Maksum, I. (2020). The Importance of Changing Management Styles in The Digital Age: The Importance of Changing Management Styles in The Digital Age. Journal of Industrial Engineering \& Management Research, 1(3), 148154. https://doi.org/10.7777/jiemar.v1i3.75

Bernarto, Bachtiar, Sudibjo, Suryawan, Purwanto \& Asbari (2020). Effect of Transformational Leadership, Perceived Organizational Support, Job Satisfaction Toward Life Satisfaction: Evidences from Indonesian Teachers. International Journal of Advanced Science and Technology, 29(3), 5495 -5503.

Fahmi, K., Kurniawan, T., Cahyono, Y., Sena, A., Suhadarliyah, Suryani, P., Sugianto, A., Amelia, D., Musnaini, Amin, S., Hasbullah, H., Jihadi, M., Wijoyo, H. \& Purwanto, A. (2020) Did Servant, Digital and Green Leadership Influence Market Performance? Evidence from Indonesian Pharmaceutical Industry. Systematic Reviews in Pharmacy, 11(9), $642-653$.

Ab Hamid, N. R., Cheng, A. Y., \& Akhir, R. M. (2011). Dimensions of E-CRM: an empirical study on hotels' web sites. Journal of Southeast Asian Research, 2(11), 1-15.

Hartono, B., \& Maksum, I. (2020). The Importance of Changing Management Styles in The Digital Age: The Importance of Changing Management Styles in The Digital Age. Journal of Industrial Engineering \& Management Research, 1(3), 148154. https://doi.org/10.7777/jiemar.v1i3.75

Hur, Y., Ko, Y., J., Valacich, J. (2011). A structural model of the relationship between sport website quality, e-satisfaction, and e-loyalty. Journal of Sport Management, 25, 462-465

Muafi, M., Syafri, W., Prabowo, H., \& Nur, S. A. (2021). Digital Entrepreneurship in Indonesia: A Human Capital Perspective. The Journal of Asian Finance, Economics and Business, 8(3), 351-359. https://doi.org/10.13106/JAFEB.2021.VOL8.NO3.0351

Naushad, M. (2021). Investigating Determinants of Entrepreneurial Leadership Among SMEs and Their Role in Sustainable Economic Development of Saudi Arabia. The Journal of Asian Finance, Economics and Business, 8(4), $225-237$. https://doi.org/10.13106/JAFEB.2021.VOL8.NO4.0225

Nugroho, B. S., Widdah, M. E., Suryana, A. T., Ibrahim, T., Humaira, M. A., Nasrudin, M., Mubarok, M. S., Abadi, M. T., Adisti, A. R., Gadzalia, S. S., Muqtada, M. R., Purwanto, .A., Fahlevi, M. \& Sudargini, Y. (2020) Effect of Leadership Style Toward Indonesian Education Performance in Education 4.0 Era: A Schematic Literature Review. Systematic Reviews in Pharmacy, 11(10), 371-378. doi:10.31838/srp.2020.10.60

Nguyen, H., Tran, T. H. M., Nguyen. H. Y., \& Truong, D. D. (2021). The Influence of Competitive Advantage on Financial Performance: A Case Study of SMEs in Vietnam. The Journal of Asian Finance, Economics and Business, 8(5), 335343. https://doi.org/10.13106/JAFEB.2021.VOL8.NO5.0335

PRAMONO, R., Sondakh, L. W., BERNARTO, I., JULIANA, J., \& PURWANTO, A. (2021). Determinants of the small and medium enterprises progress: A case study of SME entrepreneurs in Manado, Indonesia. The Journal of Asian Finance, Economics, and Business, 8(1), 881-889.

Praditya, R. A. (2020). Leadership, Work Motivation, Competency, Commitment and Culture: Which influences The Performance of Quality Management System in Automotive Industry?. Journal of Industrial Engineering \& Management Research, 1(1), 53-62. https://doi.org/10.7777/jiemar.v1i1.27 
Purwanto, A., Asbari, M., Santoso, T. I., \& Haque, M. G. (2019). Marketing Research Quantitative Analysis for Large Sample: Comparing of Lisrel, Tetrad, GSCA, Amos, SmartPLS, WarpPLS, and SPSS. Jurnal Ilmiah Ilmu Administrasi Publik, 9(2), 355-372.

Purwanto, A., Asbari, M., Santoso, T. I., Paramarta, V., \& Sunarsi, D. (2020). Social and Management Research Quantitative Analysis for Medium Sample: Comparing of Lisrel, Tetrad, GSCA, Amos, SmartPLS, WarpPLS, and SPSS. Jurnal Ilmiah Ilmu Administrasi Publik, 10(2), 518-532.

Purwanto, A., Asbari, M., \& Santoso, T. I. (2021). Education Management Research Data Analysis: Comparison of Results between Lisrel, Tetrad, GSCA, Amos, SmartPLS, WarpPLS, and SPSS For Small Samples. Nidhomul Haq: Jurnal Manajemen Pendidikan Islam, 6(2), 382-399.

Pham Thi, T. D., Ngo, A. T., Duong, N. T., \& Pham, V. K. (2021). The Influence of Organizational Culture on Employees' Satisfaction and Commitment in SMEs: A Case Study in Vietnam. The Journal of Asian Finance, Economics and Business, 8(5), 1031-1038. https://doi.org/10.13106/JAFEB.2021.VOL8.NO5.1031

Quddus, A., Nugroho, B. S., Hakim, L., Ritaudin, . M. S., Nurhasanah, E., Suarsa, . A., Karyanto, U. B., Tanjung, R., Hendar, Pratama, . V. Y., Awali, H., Mufid, A., Purwanto, . A., Fahlevi, M. \& Sudargini, Y. (2020). Effect of Ecological, Servant dan Digital Leadership Style Influence University Performance? Evidence from Indonesian Universities. Systematic Reviews in Pharmacy, 11 (10), 408-417. doi:10.31838/srp.2020.10.64

Rahaman, M. A., Luna, K. F., Ping, Z. L., Islam, M. S., \& Karim, M. M. (2021). Do Risk-Taking, Innovativeness, and Proactivity Affect Business Performance of SMEs? A Case Study in Bangladesh. The Journal of Asian Finance, Economics and Business, 8(5), 689-695. https://doi.org/10.13106/JAFEB.2021.VOL8.NO5.0689

Singhdong, P., Suthi, K., \& PornchaiL, P. (2021). Factors Influencing Digital Transformation of Logistics Service Providers: A Case Study in Thailand. The Journal of Asian Finance, Economics and Business, 8(5), $241-251$. https://doi.org/10.13106/JAFEB.2021.VOL8.NO5.0241

Suheny, E., Arum, M., Wandi, D., Rahmat, A., kurnianingsih, . A., Haerani, A., Dasmaran, V., Taryanto, , Adha, . S. \& Purwanto, A. (2020) Develop Leadership Style Model for Indonesian SMEs Leaders During Covid-19 Pandemic. Systematic Reviews in Pharmacy, 11(8), 576-586. doi:10.31838/srp.2020.8.82.

Selim, H., M. (2011) Content Evaluation Criteria for General Website: Analysis and Comparison. UAE University Working Paper Series, (3), 12-28.

Syafri, W., Prabowo, H., Nur, S. A., \& Muafi, M. (2021). The Impact of Workplace Green Behavior and Green Innovation on Green Performance of SMEs: A Case Study in Indonesia. The Journal of Asian Finance, Economics and Business, 8(5), 365-374. https://doi.org/10.13106/JAFEB.2021.VOL8.NO5.0365

Tan, J. D., Sugiarto, S., \& Budhijono, F. (2021). Family Business and Risk Management: Perspectives of SMEs Entrepreneurs in Indonesia. The Journal of Asian Finance, Economics and Business, 8(5), 851-861. https://doi.org/10.13106/JAFEB.2021.VOL8.NO5.0851

Tran, T. K. P., \& Truong, T. T. (2021). Impact of Servant Leadership on Public Service Motivation of Civil Servants: Empirical Evidence from Vietnam. The Journal of Asian Finance, Economics and Business, 8(4), $1057-1066$. https://doi.org/10.13106/JAFEB.2021.VOL8.NO4.1057

Yunarsih, N., Rahayu, S., Fatoni, Asra, ., Sustiyono, . A., Anwar, T., Sri, N. \& Purwanto, A. (2020) Develop Leadership Style Model for Nurse in Indonesian Hospital. Systematic Reviews in Pharmacy, 11(8), 352-361. doi:10.31838/srp.2020.8.53

Wanasida, A. S., Bernarto, I., Sudibjo, N., \& Purwanto, A. (2021). The Role of Business Capabilities in Supporting Organization Agility and Performance During the COVID-19 Pandemic: An Empirical Study in Indonesia. The Journal of Asian Finance, Economics and Business, 8(5), 897-911. https://doi.org/10.13106/JAFEB.2021.VOL8.NO5.0897

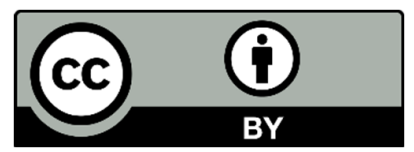

(C) 2022 by the authors; licensee Growing Science, Canada. This is an open access article distributed under the terms and conditions of the Creative Commons Attribution (CCBY) license (http://creativecommons.org/licenses/by/4.0/). 